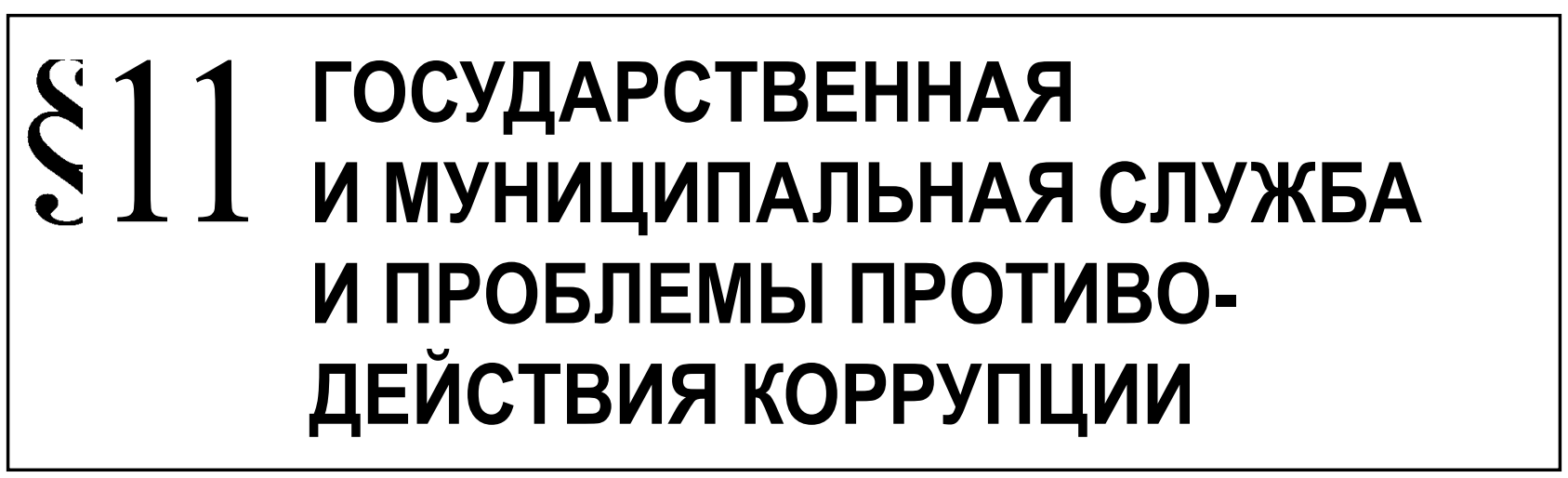

Кабанов П.А.

\title{
АНТИКОРРУПЦИОННЫЕ ФУНКЦИИ ПОДРАЗДЕЛЕНИЙ КАДРОВЫХ СЛУЖБ ПО ПРОФИЛАКТИКЕ КОРРУПЦИОННЫХ И ИНЫХ ПРАВОНАРУШЕНИЙ ОРГАНОВ ПУБЛИЧНОЙ ВЛАСТИ: ПОНЯТИЕ, СОДЕРЖАНИЕ, ВИДЫ
}

\begin{abstract}
Аннотация: В качестве предмета исследования выступают антикоррупционные функции подразделений кадровых служб органов публичной власти Российской Федерации по профилактике коррупционных и иных правонарушений.Цель исследования - описание и объяснение основных и (вспомогательных) обеспечительных функций подразделений кадровых служб органов публичной власти по профилактике коррупционных и иных правонарушений.Задачи исследования:а) описание правовых основ деятельности подразделений кадровых служб органов публичной власти по профилактике коррупционных и иных правонарушений, в которых отражены их антикоррупционные функции;б) дать классификацию антикоррупционным функциям подразделений кадровых служб органов публичной власти по профилактике коррупционных и иных правонарушений;в) раскрыть содержание антикоррупционных функций подразделений кадровых служб органов публичной власти по профилактике коррупционных и иных правонарушений. В качестве методологической основы проведенного исследования использован диалектический подход и основанные на нем общенаучные методы широко применяемые в праве: системный и структурный анализ, сравнение и другие. Научная новизна заключается в том, что впервые в российской юридической предложено определение антикоррупционных функций подразделений кадровых служб органов публичной власти по профилактике коррупционных и иных правонарушений, на основе анализа нормативных правовых актов и иных документов раскрыто их содержание, дана научная классификация антикоррупционных функций подразделений кадровых служб органов публичной власти по профилактике коррупционных и иных правонарушений.

Ключевые слова: коррупция, противодействие коррупции, кадровая служба, профилактика коррупции, антикоррупционное консультирование, антикоррупционное просвещение, антикоррупционное образование, функции, антикоррупционные функции, органы публичной власти.
\end{abstract}

$\prod$ ротиводействие коррупции - сложная и ответственная задача, возлагаемая на значительное количество субъектов противодействия коррупции с различным правовым статусом и объемом полномочий. В число субъектов, обладающих специальными полномочиями по противодействию коррупции, оказались и подразделения кадровых служб органов публичной власти Российской Федерации. Впервые их полномочия в сфере противодействия коррупции были закреплены Указом Президента Российской Федерации от 15 мая 1997 года «О представлении лицами, замещающими государственные должности Российской Федерации, и лицами, замещающими государственные должности государственной службы и должности в органах местного самоуправления, сведений о доходах и имуществе». В соответствии с этим нормативным актом, кадровая служба со- 
ответствующего государственного органа в случае обнаружения признаков недостоверности или неполноты представленных сведений о доходах и имуществе лицами, замещающими государственные должности Российской Федерации, государственными служащими и лицами, замещающими должности в органах местного самоуправления обязана была организовать их проверку. ${ }^{1}$ Вслед за этим аналогичные положения, наделяющие кадровые службами полномочиями по проверке достоверности и полноты сведений о доходах и имуществе государственных служащих и лиц, замещающих государственные должности субъектов Российской Федерации, были закреплены в нормативных правовых актах субъектов Российской Федерации. ${ }^{2}$

В связи с изложенным можно утверждать, что именно с этого времени на федеральном и региональном уровне была закреплена антикоррупционная функция осуществления кадровыми службами органов публичной власти, проверки достоверности сведений о доходах и имуществе государственных (муниципальных) служащих и лиц, замещающих государственные и муниципальные должности. Эта функция, закрепленная за кадровыми подразделениями федеральных органов государственной власти, существовала до замены названного Указа Президента Российской Федерации новым нормативным правовым актом по данному вопросу в мае 2009 года. ${ }^{3}$ Однако такое положение дел просуществовало не большой промежуток времени - до сентября 2009 года, когда решением Президента Российской Федерации было предложено формирование специализированных подразделе-

\footnotetext{
1 О представлении лицами, замещающими государственные должности Российской Федерации, и лицами, замещающими государственные должности государственной службы и должности в органах местного самоуправления, сведений о доходах и имуществе: Указ Президента РФ от 15.05.1997 №484 // Собрание законодательства РФ. - 1997. - №20. Ст. 2239.

2 О представлении лицами, замещающими государственные должности в Республике Татарстан, сведений о доходах и имуществе: Указ Президента РТ от 18.07.1997 №УП-376 (ред. от 23.03.2005) // Ведомости Государственного Совета Татарстана. - 1997. - №8-9. - Ст. 241.

3 О представлении гражданами, претендующими на замещение должностей федеральных государственных служащих, и федеральными государственными служащими сведений о доходах, об имуществе и обязательствах имущественного характера: Указ Президента Российской Федерации от 18 мая 2009 года №559 // Собрание законодательства РФ. - 2009. - №21. - Ст. 2544.
}

ний кадровых служб по профилактике коррупционных и иных правонарушений с возложением на них ряда антикоррупционных функций. Принятие названных нормативных правовых актов не сопровождалось предварительной глубокой научной разработкой основ деятельности подразделений кадровых служб по профилактике коррупционных и иных правонарушений, не осуществляются серьезные научные разработки в этом направлении и в настоящее время. Можно лишь указать несколько небольших по объему научных работ, которые посвящены вопросам деятельности кадровых служб по профилактике коррупционных и иных правонарушений $[3$, с.160-161; 7, с.116-124; 8, с.15-20; 12, c.76-81]. Вместе с тем, уже имеются и специализированные антикоррупционные образовательные программы дополнительного профессионального образования по организации деятельности подразделений кадровых служб органов публичной власти по профилактике коррупционных и иных правонарушений, реализуемые Российской академией государственной службы и народного хозяйства при Президенте Российской Федерации [15], Институтом экономики, управления и права (г. Казань) [4] и другими образовательными учреждениями. Хотя об отдельных функциях и направлениях деятельности подразделений кадровых служб по профилактике коррупционных и иных правонарушений отечественными специалистами в своих работах упоминается в связи с осуществлением мер по противодействию коррупции [2, с.135-198; 5, с.8-64; 16, с.40-50]. Однако их явно недостаточно для повышения эффективности противодействия коррупции подразделениями кадровых служб по профилактике коррупционных и иных правонарушений.

Такое положение дел в данной сфере деятельности требует организации и активизации научных исследований отечественных специалистов, занимающихся вопросами совершенствования государственной политики противодействия коррупции. Это положение в общем виде, собственно, и содержится в Национальном плане противодействия коррупции на 2014-2015 годы, ${ }^{4}$ но практическая значимость таких исследований заключается ещё и в том, что этим же планом президиуму Coвета при Президенте Российской Федерации и Пра-

\footnotetext{
4 О Национальном плане противодействия коррупции на 2014-2015 годы: Указ Президента Российской Федерации от 11 апреля 2014 года №226 // Собрание законодательства РФ. 2014. - №15. - Ст.1729.
} 
вительству Российской Федерации предложена разработка проекта типового положения о подразделениях органов государственной власти субъектов Российской Федерации по профилактике коррупционных и иных правонарушений. В связи с этим научное и научно-методическое обеспечение деятельности подразделений кадровых служб по профилактике коррупционных и иных правонарушений является не только актуальной проблемой, но и практически значимой.

Среди наиболее значимых вопросов подлежащих исследованию в сфере деятельности кадровых служб органов публичной власти по профилактике коррупционных и иных правонарушений являются такие проблемы как: антикоррупционные функции этих подразделений; особенности осуществления ими дисциплинарного производства по делам о коррупционных проступках; особенности обеспечения ими деятельности специализированных антикоррупционных совещательных органов, а также оценка эффективности деятельности этих подразделений. Разумеется, что в одной не большой по объему работе названные вопросы полно и всесторонне исследовать и описать невозможно, то мы ограничимся лишь рассмотрением одного из основных вопросов - содержанию антикоррупционных функций, возлагаемых на подразделения кадровых служб органов государственной власти и органов местного самоуправления по профилактике коррупционных и иных правонарушений.

Для достижения заявленной нами цели необходимо обратиться к правовому регулированию деятельности подразделений кадровых служб органов публичной власти по профилактике коррупционных и иных правонарушений. Здесь мы можем с уверенностью сказать, что правовой основой формирования подразделений кадровых служб по профилактике коррупционных и иных правонарушений в органах государственной власти и органах местного самоуправления стал Указ Президент Российской Федерации от 21 сентября 2009 года «О проверке достоверности и полноты сведений, представляемых гражданами, претендующими на замещение должностей федеральной государственной службы, и федеральными государственными служащими, и соблюдения федеральными государственными служащими требований к служебному поведению». В этом нормативном правовом акте, предписывалось:

a) федеральным органам исполнительной власти - создание подразделений кадровых служб по профилактике коррупционных и иных правонарушений;

б) федеральным государственным органам определить подразделения по профилактике коррупционных и иных правонарушений;

в) органам государственной власти субъектов Российской Федерации, органам местного самоуправления руководствоваться положениями этого нормативного правового акта при разработке собственных положений по данному направлению деятельности;

г) правительству Российской Федерации - подготовка проекта типового положения о подразделениях кадровых служб федеральных государственных органов по профилактике коррупционных и иных правонарушений. ${ }^{5}$

В качестве основных направлений деятельности подразделений кадровых служб по профилактике коррупционных и иных правонарушений органов публичной власти этим документом были закреплены несколько относительно самостоятельных антикоррупционных функций, правовое регулирование которых не ограничивалось только нормативными правовыми актами о деятельности названных служб, но и другими. Однако, для более точного раскрытия содержания антикоррупционных функций подразделений кадровых служб публичной власти по профилактике коррупционных и иных правонарушений органов необходимо определиться с понятием антикоррупционная функция и её разновидностями.

Как нам представляется, под антикоррупционной функцией подразделения органа публичной власти по профилактике коррупционных и иных правонарушений следует понимать регулярно осуществляемую органом публичной власти деятельность по реализации или обеспечению реализации государственной политики противодействия коррупции. При этом можно условно разделить антикоррупционные функции подразделения по профилактике коррупционных и иных правонарушений органа публичной власти на две категории: основные, осуществляемые для достижения целей их создания и вспомогательные (обеспечи-

О проверке достоверности и полноты сведений, представляемых гражданами, претендующими на замещение должностей федеральной государственной службы, и федеральными государственными служащими, и соблюдения федеральными государственными служащими требований к служебному поведению: Указ Президента Российской Федерации от 21 сентября 2009 года №1065 (в ред. от 11.04. 2014 №226) // Российская газета. - 2009. - 22 сент. 
тельные), осуществляемые в целях выполнения основных функций. Следует отметить, что эти антикоррупционные функции подразделений по профилактике коррупционных и иных правонарушений взаимосвязанные, взаимозависимые и взаимодополняемые.

На наша взгляд, в качестве основной функции деятельности подразделения кадровой службы органа публичной власти по профилактике коррупционных и иных правонарушений в президентском указе закреплена функция обеспечения соблюдения государственными (муниципальными) служащими и иными лицами антикоррупционных ограничений, запретов и требований. Эта функция сформулирована в нормативном акте достаточно громоздко «обеспечение соблюдения государственными служащими ограничений $и$ запретов, требований о предотвращении или урегулировании конфликта интересов, исполнения ими обязанностей, установленных Федеральным законом от 25 декабря 2008 года №273-Ф3 «0 противодействии коррупции» и другими федеральными законами». Данная функция в последующем была закреплена за подразделениями кадровых служб органов публичной власти по профилактике коррупционных и иных правонарушений в федеральном антикоррупционном законодательстве ${ }^{6}$ и других нормативных правовых актах. ${ }^{7}$

Безусловно, в число основных функций подразделения органа публичной власти по профилактике коррупционных и иных правонарушений является профилактика коррупции, иногда именуемая антикоррупционной профилактикой $[1$, c.14; 6, c.9] в узком понимании этого термина как принятие мер по выявлению и устранению причин и условий, способствующих возникновению конфликта интересов на государственной (муни-

\footnotetext{
6 О контроле за соответствием расходов лиц, замещающих государственные должности, и иных лиц их доходам: Федеральный закон от 3 декабря 2012 года №230-Ф3 // Собрание законодательства РФ. - 2012. - №50 (часть 4). - Ст.6953; О запрете отдельным категориям лиц открывать и иметь счета (вклады), хранить наличные денежные средства и ценности в иностранных банках, расположенных за пределами территории Российской Федерации, владеть и (или) пользоваться иностранными финансовыми инструментами: Федеральный закон от 07.05.2013 № 79-Ф3 // Собрание законодательства РФ. - 2013. - №19. - Ст. 2306.

7 Об утверждении Положения об Управлении Президента Российской Федерации по вопросам государственной службы и кадров: Указ Президента Российской Федерации от 4 декабря 2009 года №1382 (в ред. от 28.07.2012 №1065) // Собрание законодательства РФ. - 2009. - №49 (Ч. 2). - Ст.5922.
}

ципальной) службе. ${ }^{8}$ Однако, в методических рекомендациях, одобренных президиумом Совета при Президенте Российской Федерации по противодействию коррупции по данному вопросу дается несколько иное расширительное толкование содержанию профилактике коррупции как функции подразделения кадровой службы органа публичной власти по профилактике коррупционных и иных правонарушений, охватывающей всю деятельность по выявлению и устранению причин и условий, способствующих совершению коррупционных правонарушений [14, с.3].

В числе основных функций подразделений кадровых служб органов публичной власти по профилактике коррупционных и иных правонарушений рассматриваемым указом Президента Российской Федерации была закреплена функция антикоррупџионного консультирования государственных (муниципальных) служащих. Эта функция в нормативном правовом акте была сформулирована следующим образом: «оказание государственным служащим консультативной помощи по вопросам, связанным с применением требований к служебному поведению и общих принципов служебного поведения государственных служащих, а также с уведомлением представителя нанимателя (работодателя), органов прокуратуры Российской Федерации, иных федеральных государственных органов о фактах совершения государственными служащими, государственными служащими субъектов Российской Федерации или муниципальными служащими коррупционных правонарушений непредставления ими сведений либо представления недостоверных или неполных сведений о доходах, об имуществе и обязательствах имущественного характера».

Близкой по содержанию с антикоррупционным консультированием государственных (муниципальных) служащих на подразделения кадровых служб органов публичной власти по профилактике коррупционных и иных правонарушений была возложена функция по организации антикоррупционного просвещения государственных (муниципальных) служащих, которая была сформулирована как «организация правового просвещения государственных служащих». Здесь при наимено-

\footnotetext{
8 О профилактике коррупционных и иных правонарушений в Федеральном агентстве по делам Содружества Независимых Государств, соотечественников, проживающих за рубежом, и по международному гуманитарному сотрудничеству: Приказ Россотрудничества от 09.07.2013 №0123-пр.
} 
вании функции предпочтительнее выглядит словосочетание «антикоррупционное просвещение», чем «правовое просвещение», которые иногда, по непонятным причинам, даже в официальных документах неоправданно отождествляются. ${ }^{9}$ Для осуществления этой функции подразделения кадровых служб по профилактике коррупционных и иных правонарушений занимаются разработкой методических рекомендаций по вопросам соблюдения государственными (муниципальными) служащими и иными лицами антикоррупционных требований $[9 ; 10 ; 11]$.

Более того, методическими рекомендациями президиума Совета при Президенте Российской Федерации наравне с профилактическими антикоррупционными функциями антикоррупционного консультирования и антикоррупционного просвещения на подразделения кадровых служб по профилактике коррупционных и иных правонарушений было рекомендовано возложить функцию антикоррупционного образования государственных (муниципальных) служащих по программам дополнительного профессионального образования, названную правовое обучение по вопросам противодействия коррупции, соблюдения ими запретов, ограничений, требований к служебному поведению [14, с.5-6]. Эта основная антикоррупционная функция подразделений кадровых служб по профилактике коррупционных и иных правонарушений органов публичной власти была в последующем закреплена в отдельных региональных нормативных правовых актах. ${ }^{10}$

Пожалуй, одной из важнейших функций подразделений кадровых служб органов публичной власти по профилактике коррупционных и иных правонарушений стала функция ведения дисциплинарного производства о соблюдении государственными (муниципальными) служсащими антикоррупционных ограничений, запретов и требований, которая оказалась изложенной в

\footnotetext{
9 Об утверждении Программы по антикоррупционному просвещению на 2014-2016 годы: Распоряжение Правительства Российской Федерации от 14 мая 2014 года №816-р // Собрание законодательства РФ. - 2014. - №21. - Ст.2721.

10 О мониторинге деятельности структурных подразделений (соответствующих должностных лиц) органов государственной власти Ямало-Ненецкого автономного округа, иных государственных органов Ямало-Ненецкого автономного округа по профилактике коррупционных и иных правонарушений: Постановление Губернатора ЯНАО от 26.06.2012 № 88-ПГ (ред. от 23.04.2013 №46-ПГ) // Красный Север. - 2012. - 6 июля.
}

двух самостоятельных разделах. Первый раздел был именован «проведение служебных проверок», а второй «осуществление проверки достоверности и полноты сведений о доходах, об имуществе и обязательствах имущественного характера, представляемых гражданами, претендующими на замещение должностей федеральной государственной службы, и федеральными государственными служащими, сведений, представляемых гражданами, претендующими на замещение должностей федеральной государственной службы, в соответствии с нормативными правовыми актами Российской Федерации, проверки соблюдения федеральными государственными служащими требований к служебному поведению, а также проверки соблюдения гражданами, замещавшими должности государственной службы, ограничений при заключении ими после ухода с государственной службы трудового договора и (или) гражданско-правового договора в случаях, предусмотренных федеральными законами». Это функцию можно было бы отнести и к группе обеспечительных функций, поскольку она носит процессуальный характер по отношению к основной функции обеспечения соблюдения государственными служащими антикоррупционных ограничений, запретов и требований. Безусловно, она носит производный характер от основной, но она не менее важна, поскольку без её осуществления, невозможно реализовать механизмы ответственности за коррупционные дисциплинарные проступки. Вопросам реализации этой функции подразделениями кадровых служб по профилактике коррупционных и иных правонарушений органов публичной власти посвящено множество нормативных правовых актов различного уровня. ${ }^{11}$ Данное положение в последующем было закреплено и в ряде федеральных законов, в том числе и регулирующих прохождение государственной гражданской службы. ${ }^{12}$

\footnotetext{
11 См., например: О проверке достоверности и полноты сведений, представляемых гражданами, претендующими на замещение должностей государственной гражданской службы Владимирской области, и государственными гражданскими служащими Владимирской области, и соблюдения государственными гражданскими служащими Владимирской области требований к служебному поведению: Закон Владимирской области от 5 апреля 2010 года № 23О3 (в ред. от 13.08.2012 №85-О3) // Владимирские ведомости. - 2010. - 7 апр.

12 О государственной гражданской службе Российской Федерации: Федеральный закон от 27 июля 2004 года №79-Ф3 //Собрание законодательства РФ. - 2004. - №31. - Ст.3215.
} 
Этим же нормативным правовым актом Президент Российской Федерации предусмотрел участие в антикоррупционном правотворчестве подразделений кадровых служб органов публичной власти по профилактике коррупционных и иных правонарушений, сформулировав эту антикоррупционную функцию «подготовкой проектов нормативных правовых актов о противодействии коррупции».

В качестве вспомогательных (обеспечительных) функций подразделений кадровой службы органов публичной власти по профилактике коррупционных и иных правонарушений в нормативном правовом акте были указаны лишь три. Первой по значимости стала функция обеспечения деятельности комиссий по соблюдению требований к служебному поведению государственных служащих и урегулированию конфликта интересов, выступающая в качестве одного из инструментов реализации основной функции обеспечение соблюдения государственными служащими антикоррупционных ограничений, запретов и требований. Правовое закрепление этой функции за подразделениями кадровой службы органов публичной власти по профилактике коррупционных и иных правонарушений произошло на различных уровнях и различными по правовой природе нормативными правовыми актами. ${ }^{13}$

Второй вспомогательной антикоррупционной функцией подразделений кадровой службы органов публичной власти по профилактике коррупционных и иных правонарушений является функция обеспечения реализации государственными служащими обязанности уведомлять представителя нанимателя (работодателя), органы прокуратуры Российской Федерации, иные федеральные государственные органы обо всех случаях обращения к ним каких-либо лиц в целях склонения их к совершению коррупционных правонарушений. Здесь тоже мы можем обнаружить значительное количество ведомственных нормативных правовых актов, в которых эта функция закреплена за подразделениями кадровых служб органов публичной власти по профилактике коррупционных и иных правонарушений. ${ }^{14}$

\footnotetext{
13 См., например: О комиссиях по соблюдению требований к служебному поведению государственных гражданских служащих Оренбургской области и урегулированию конфликта интересов: Закон Оренбургской области от 18 ноября 2011 года №576/149-V-O3 // Оренбуржье. - 2011. - 2 декаб.

14 См., например: О порядке уведомления федеральными государственными гражданскими служащими Мин-
}

Третьей вспомогательной антикоррупционной функцией подразделений кадровых служб органов публичной власти по профилактике коррупционных и иных правонарушений была закреплена функция взаимодействия с правоохранительными органами в сфере противодействия коррупции. $^{15}$ Эта функция и механизмы её осуществления достаточно подробно освещены в методических рекомендациях по данному вопросу, одобренных президиумом Совета при Президенте Российской Федерации по противодействию коррупции [13] и некоторых региональных нормативных правовых актах. ${ }^{16}$

Закрепленные в Указе Президента Российской Федерации основные и вспомогательные антикоррупционные функции подразделений органов публичной власти по профилактике коррупционных и иных правонарушений в последующем стали активно закрепляться нормативными правовыми актами за подразделениями кадровых служб федеральных органов государственной власти ${ }^{17}$ либо

фина России и назначаемыми на должность Министром финансов Российской Федерации федеральными государственными гражданскими служащими федеральных служб, находящихся в ведении Минфина России, и их территориальных органов представителя нанимателя (работодателя) о фактах обращения в целях склонения их к совершению коррупционных правонарушений, регистрации таких уведомлений и проверки содержащихся в них сведений: Приказ Минфина РФ от 11.12.2009 №130н // Российская газета. - 2010. - 12 марта; Об утверждении Порядка уведомления работодателя о фактах обращения в целях склонения работников организаций, созданных для выполнения задач, поставленных перед Министерством сельского хозяйства Российской Федерации, к совершению коррупционных правонарушений: Приказ Минсельхоза России от 4 декабря 2013 года № 448 // Российская газета. - 2014. - 19 февр.

15 О проверке достоверности и полноты сведений, представляемых гражданами, претендующими на замещение должностей федеральной государственной службы, и федеральными государственными служащими, и соблюдения федеральными государственными служащими требований к служебному поведению: Указ Президента Российской Федерации от 21 сентября 2009 года №1065 (в ред. от 11.04. 2014 №226) // Российская газета. - 2009. - 22 сент.

16 О мерах по взаимодействию с правоохранительными органами в сфере противодействия коррупции: распоряжение Администрации Псковской области от 26 августа 2010 года №229-p.

17 О мерах по реализации указов Президента Российской Федерации от 18 мая 2009 г. №559, от 21 сентября 2009 г. №1065, от 2 апреля 2013 г. №309, от 2 апреля 2013 г. №310 и от 8 июля 2013 г. №613: Постановление Правительства РФ от 03.12.2009 №987 
возлагаться на определенные структурные подразделения государственных органов или их должностных лиц. ${ }^{18}$

Для однообразного закрепления антикоррупционных функций в федеральных государственных органах в феврале 2010 года Аппаратом Правительства Российской Федерации было принято типовое Положение о подразделении по профилактике коррупционных и иных правонарушений кадровой службы федерального государственного органа (далее по тексту - типовое положение - $п р и$ мечание автора - П.К.), которым на подразделения федеральных государственных органов по профилактике коррупционных и иных правонарушений были возложены дополнительные функции. Эти антикоррупционные функции носили в основном вспомогательный характер и были направлены на обеспечение основных функций. Наиболее значимой дополнительной антикоррупционной функцией подразделений по профилактике коррупционных и иных правонарушений стала функция по контролю за соблюдением антикоррупционных ограничений, запретов и требований, которая заключается в «соборе и обработке сведений о доходах, об имуществе и обязательствах имуществен-

(в ред. от 18.11.2013) // Собрание законодательства РФ. 2009. - №49 (2 ч.). - Ст. 5985; О возложении полномочий по профилактике коррупционных и иных правонарушений: Приказ Федерального агентства по управлению государственным имуществом от 3 ноября 2009 года №305; O реализации Указа Президента Российской Федерации от 21 сентября 2009 г. №1065: Приказ Федерального космического агентства от 16 марта 2010 года №42; О должностных лицах отдела кадров Рособоронзаказа, ответственных за работу по профилактике коррупционных и иных правонарушений: Приказ Федеральной службы по оборонному заказу от 24 ноября 2009 года №396; Об определении в территориальных органах Федерального агентства воздушного транспорта должностных лиц, ответственных за работу по профилактике коррупционных и иных правонарушений: Приказ Федерального агентства воздушного транспорта от 5 ноября 2009 года № 488; Об утверждении Положения об обязанностях должностного лица, ответственного за работу по профилактике коррупционных и иных правонарушений в Федеральной службе по надзору за соблюдением законодательства в области охраны культурного наследия: Приказ Росохранкультуры от 31 марта 2010 года №52 и др.

18 О возложении функции по профилактике коррупционных и иных правонарушений в Министерстве обороны Российской Федерации: Приказ Министра обороны РФ от 22 октября 2009 года №1115; О реализации Указа Президента Российской Федерации от 21 сентября 2009 г. № 1065: Приказ Федерального космического агентства от 16 марта 2010 года №42. ного характера, представленные в установленном порядке, а также осуществлению контроля за своевременностью их представления».

Не менее значимой оказалось и закрепление за подразделениями органов публичной власти по профилактике коррупционных и иных правонарушений такой функции как содействие антикоррупционному информированию, то есть обеспечению подготовки сведений о доходах, об имуществе и обязательствах имущественного характера, подлежащих размещению на официальном сайте государственного органа.

Ещё одна вспомогательная функция подразделений органов публичной власти по профилактике коррупционных и иных правонарушений была сформулирована как обеспечение сохранности и конфиденциальности сведений о государственных служащих, полученных в ходе своей деятельности, связанной с противодействием коррупции. ${ }^{19}$

Закрепление дополнительных антикоррупционных функций за подразделениями кадровых служб по профилактике коррупционных и иных правонарушений этим нормативным правовым актом повлияло на правовое регулирование их деятельности в федеральных органах исполнительной власти. ${ }^{20} \mathrm{C}$ учетом специфики деятельности подразделений кадровых служб по профилактике коррупционных и иных правонарушений на ведомственном, региональном и муниципальном уров-

19 Типовое Положение о подразделении по профилактике коррупционных и иных правонарушений кадровой службы федерального государственного органа, утвержденное заместителем Председателя Правительства РФ 18 февраля 2010 года №647п-П16.

20 О реализации Указа Президента Российской Федерации от 21 сентября 2009 г. №1065: Приказ Роскосмоса от 16.03.2010 №42; О направлении методических рекомендаций по противодействию коррупции: Письмо Минобрнауки России от 06.08.2013 №12-925 // Официальные документы в образовании. - 2013. - №o 34 - 36; Об утверждении Положения об осуществлении подразделением по профилактике коррупционных и иных правонарушений (должностным лицом, ответственным за работу по профилактике коррупционных и иных правонарушений) Федеральной службы государственной статистики (территориального органа Федеральной службы государственной статистики) проверки достоверности и полноты сведений, представляемых гражданами, претендующими на замещение должностей федеральной государственной гражданской службы, и федеральными государственными гражданскими служащими, и соблюдения федеральными государственными гражданскими служащими требований к служебному поведению: Приказ Федеральной службы государственной статистики от 8 июля 2013 года №270 // Российская газета. - 2013. - 21 нояб. 
нях за ними стали закрепляться новые полномочия и функции, связанные с исполнением положений изменяющегося федерального антикоррупционного законодательства. Так, в Росздравнадзоре в качестве функций отдела по профилактике коррупционных и иных правонарушений дополнительно к основным функциям, предусматривается и ряд дополнительных.

В соответствии с изменениями в антикоррупционном законодательстве, связанном с расширением перечня лиц, обязанных предоставлять сведения о доходах, об имуществе и обязательствах имущественного характера, а также в связи с обязанностью отдельных лиц, представлять сведения о расходах, на это подразделение кадровой службы было возложено осуществление проверки достоверности и полноты сведений о доходах, расходах, об имуществе и обязательствах имущественного характера, представляемых руководителями подведомственных Росздравнадзору учреждений, то есть предусмотрено расширение их полномочий по кругу лиц. Указанное положение нормативного правового акта в полном объеме соответствует положениям действующего федерального антикоррупционного законодательства, расширившего перечень лиц, на которых распространяются антикоррупционные ограничения, запреты и требования, и требует заимствования другими органами публичной власти при формировании правовой базы деятельности подразделений кадровых служб по профилактике коррупционных и иных правонарушений.

Не менее важной вспомогательной антикоррупционной функцией названного отдела Росздравнадзора является прием письменных и устных обращений граждан по вопросам противодействия коррупции, их своевременное и полное рассмотрение. Эта функция нашла своё закрепление и в других нормативных правовых актах органов публичной власти. ${ }^{21}$

К вспомогательной антикоррупционной функции отдела по профилактике коррупционных и иных правонарушений Росздравнадзора относится и функция организации и участие в проведении

21 Об утверждении положений «О работе горячей линии по вопросам противодействия коррупции» и “Ящика доверия" для письменных обращений граждан по вопросам коррупционной направленности в муниципальном образовании город Набережные Челны: Постановление Мэра г. Набережные Челны от 1 июля 2014 года №M 381//Челнинские известия. - 2014. - 9 июля. совещаний, конференций и семинаров по вопросам противодействия коррупции.

В числе вспомогательных антикоррупционных функций отдела закреплено осуществление взаимодействия с другими структурными подразделениями государственного органа по вопросам противодействия коррупции.

Учитывая, изменяющееся федеральное антикоррупционное законодательства в исследуемом нормативном правовом акте предусмотрено осуществление иных функций в сфере противодействия коррупции, если такие функции предусмотрены федеральными законами, нормативными правовыми актами Президента Российской Федерации или Правительства Российской Федерации. ${ }^{22}$ Как показывает практика антикоррупционной деятельности, чаще всего иной антикоррупционной функцией подразделений кадровых служб органов публичной власти выступает ведение делопроизводства по вопросам антикоррупционной деятельности в органе государственной власти или органе местного самоуправления.

В некоторых органах государственной власти дополнительно закрепляются и некоторые другие функции. Например, в Федеральной службе по оборонному заказу на подразделения кадровой службы по профилактике коррупционных и иных правонарушений возложена функция обеспечения подачи федеральными государственными гражданскими служащими Рособоронзаказа заявления о передаче в Рособоронзаказ подарков, полученных в связи с протокольными мероприятиями, служебными командировками и другими официальными мероприятиями. ${ }^{23}$ На наш взгляд, данное направление деятельности является не самостоятельной функцией, а частью более общего направления деятельности - обеспечение соблюдения государственными служащими антикоррупционных ограничений, запретов и требований, поскольку эти антикоррупционные требования закреплены в ряде нормативных правовых актов различного уровня, в том числе постановлении Правительства

\footnotetext{
22 Об утверждении положений об Управлении государственной службы, кадров, антикоррупционной и правовой работы и отделах Управления государственной службы, кадров, антикоррупционной и правовой работы: Приказ Федеральной службы по надзору в сфере здравоохранения от 1 апреля 2013 года №1122-Пр/13.

23 О должностных лицах отдела государственной службы и кадров Рособоронзаказа, ответственных за работу по профилактике коррупционных и иных правонарушений: Приказ Рособоронзаказа от 29 апреля 2013 года №52.
} 
Российской Федерации ${ }^{24}$ и ведомственном нормативном правовом акте. ${ }^{25}$

После принятия подзаконных нормативных актов на федеральном уровне, правовое регулирование деятельности подразделений кадровых служб по профилактике коррупционных и иных правонарушений осуществляется на региональном и муниципальном уровнях. При этом основные функции этих подразделений и должностных лиц, соответствуют типовому Положению, а в некоторых субъектах Российской Федерации принимаются собственные типовые Положения. Например, в Республики Северная Осетия-Алания распоряжением главы этого субъекта Российской Федерации принято Типовое положение о подразделении по профилактике коррупционных и иных правонарушений кадровой службы государственного органа Республики Северная Осетия-Алания, ${ }^{26}$ полностью совпадающее по содержанию с федеральным типовым Положением. В Саратовской области постановлением Губернатора принято типовое Положение о подразделении кадровой службы государственного органа Саратовской области по профилактике коррупционных и иных правонарушений, ${ }^{27}$ которое практически полностью соответствует федеральному типовому Положению. Однако в нем имеется дополнительная функция подразделения кадровой службы госу-

24 О порядке сообщения отдельными категориями лиц о получении подарка в связи с их должностным положением или исполнением ими служебных (должностных) обязанностей, сдачи и оценки подарка, реализации (выкупа) и зачисления средств, вырученных от его реализации: Постановление Правительства РФ от 09.01.2014 № 10 // Собрание законодательства РФ. - 2014. - №3. - Ст.279.

25 О порядке передачи в Рособоронзаказ подарков, полученных федеральными государственными гражданскими служащими центрального аппарата Рособоронзаказа в связи с протокольными мероприятиям, служебными командировками м другими официальными мероприятиями: Приказ Рособоронзаказа от 15 августа 2011 года №284.

26 О Типовом положении о подразделении по профилактике коррупционных и иных правонарушений кадровой службы государственного органа Республики Северная Осетия-Алания: Распоряжение Главы Республики Северная Осетия-Алания от 11 сентября 2012 года №163-рг

27 Об утверждении Типового положения о подразделении кадровой службы государственного органа Саратовской области по профилактике коррупционных и иных правонарушений: Постановление Губернатора Саратовской области от 4 октября 2010года №220 (ред. от 19.10.2010 №229) // Собрание законодательства Саратовской области. - 2010. - №28. сентябрь-октябрь. дарственного органа по профилактике коррупционных и иных правонарушений - обеспечивает представление письменного обращения Губернатору области с просьбой о направлении запроса о проведении оперативно-розыскных мероприятий в соответствии с пунктом 7 части второй статьи 7 Федерального закона «Об оперативно-розыскной деятельности» с приложением проекта запроса. На наш взгляд, этот вид не деятельности не является функцией, а лишь отражает специфику деятельности при осуществлении дисциплинарного производства, что составляет лишь часть более общей функции ведения дисциплинарного производства о соблюдении государственными (муниципальными) служащими антикоррупционных ограничений, запретов и требований.

Вместе с тем в процессе правового регулирования антикоррупционной деятельности кадровых служб органов государственной власти субъектов Российской Федерации к их полномочиям относилось и относится исполнение функции подготовки перечня должностей государственного органа, при назначении на которые и при замещении которых гражданские служащие обязаны предоставлять сведения о доходах, об имуществе и обязательствах имущественного характера. ${ }^{28}$ Хотя, на наш взгляд, эта деятельность подразделений кадровых служб органов публичной власти по профилактике коррупционных и иных правонарушений является частью основной функции - участие в антикоррупционном правотворчестве.

На наш взгляд, необходимо обратить внимание на ещё одну вспомогательную функцию подразделений кадровых служб органов публичной власти по профилактике коррупционных и иных правонарушений, которая была описана в методических рекомендациях президиума Совета при Президенте Российской Федерации по противодействию коррупции - это функция осуществление внутреннего антикоррупционного мониторинга в органе публичной власти. Данную функцию разработчики рекомендаций назвали очень громоздко «регулярный мониторинг выявленных в федеральном государственном органе коррупционных правонарушений, случаев несоблюдения запретов, ограничений, требований к служебному поведе-

\footnotetext{
28 О Типовом положении о структурном подразделении по вопросам государственной службы и кадров государственного органа города Москвы: Указ Мэра Москвы от 2 ноября 2009 года №82-УМ (в ред. от 22.07.2011 №55-УМ) // Вестник Мэра и Правительства Москвы. - 2009. - 10 нояб. - №62.
} 
нию государственного служащего, ситуаций конфликта интересов, а также этически спорных ситуаций» [14, с.13-14]. Эта функция также нашла своё отражение в ряде ведомственных нормативных правовых актов, регулирующих вопросы противодействия коррупции, но в первую очередь в ведомственных планах противодействия коррупции.

Проведенный нами анализ содержания нормативных правовых актов, регулирующих деятельность подразделений кадровых служб органов государственной власти по профилактике коррупционных и иных правонарушений, позволяет сделать некоторые выводы.

Во-первых, антикоррупционная функция подразделения кадровой службы органов публичной власти по профилактике коррупционных и иных правонарушений - это регулярно осуществляемая специализированным подразделением кадровой службы органа публичной власти по профилактике коррупционных и иных правонарушений деятельность по реализации или обеспечению реализации государственной политики противодействия коррупции.

Во-вторых, антикоррупционные функции подразделений кадровых служб органов публичной власти по профилактике коррупционных и иных правонарушений можно условно разделить на две взаимосвязанные группы: основные и вспомогательные.

В-третьих, основными функциями подразделений кадровых служб органов публичной власти по профилактике коррупционных и иных правонарушений являются:

1) профилактика коррупции в органах публичной власти и подведомственных учреждениях;

2) обеспечение соблюдения государственными (муниципальными) служащими и иными лицами антикоррупционных ограничений, запретов и требований;

3) антикоррупционное консультирование государственных (муниципальных) служащих и иных лиц;

4) организация антикоррупционного просвещения государственных (муниципальных) служащих и иных лиц;

5) организация антикоррупционного образования государственных (муниципальных) служащих и иных лиц по программам дополнительного профессионального образования;

6) ведение дисциплинарного производства о соблюдении государственными (муниципальными) служащими и иными лицами анти- коррупционных ограничений, запретов и требований;

7) участие в антикоррупционном правотворчестве;

8) содействие антикоррупционному информированию.

В-четвертых, вспомогательными (обеспечительными) функциями подразделений кадровых служб органов публичной власти по профилактике коррупционных и иных правонарушений являются:

1) обеспечение деятельности комиссий по соблюдению требований к служебному поведению государственных (муниципальных) служащих и урегулированию конфликта интересов;

2) обеспечение реализации государственными служащими обязанности уведомлять представителя нанимателя (работодателя), органы прокуратуры Российской Федерации, иные федеральные государственные органы обо всех случаях обращения к ним каких-либо лиц в целях склонения их к совершению коррупционных правонарушений;

3) взаимодействие с правоохранительными органами по вопросам противодействия коррупции;

4) обеспечение сохранности и конфиденциальность сведений о государственных служащих, полученных в ходе антикоррупционной деятельности;

5) прием письменных и устных обращений граждан по вопросам противодействия коррупции, их своевременное и полное рассмотрение;

6) организации и участие в проведении совещаний, конференций и семинаров по вопросам противодействия коррупции;

7) ведение делопроизводства по вопросам антикоррупционной деятельности в органе государственной власти;

8) осуществление внутреннего антикоррупционного мониторинга в органе публичной власти. Разумеется, что проведенное нами исследование содержания антикоррупционных функций подразделений кадровых служб органов публичной власти по профилактике коррупционных и иных правонарушений не является исчерпывающим. Необходимо дальнейшее исследование практики исполнения этих функций подразделениями кадровых служб органов публичной власти по профилактике коррупционных и иных правонарушений на федеральном, региональном и муниципальном уровне. 


\section{Библиография:}

1. Агеев В.Н., Бикеев И.И., Кабанов П.А и др. Всё о коррупции и противодействии ей: терминологический словарь / под общ. ред. И.И. Бикеева, П.А. Кабанова. - Казань: Изд-во «Познание» Института экономки, управления и права, 2014.

2. Андриченко Л.В., Беляева О.А., Васильев И.В. и др. Противодействие коррупции в субъектах Российской Федерации: научно-практическое пособие / под ред. Т.Я. Хабриевой. - М., 2013. - С.135-198.

3. Белов А.Н. О деятельности должностных лиц кадровых служб органов государственной власти и органов местного самоуправления по профилактике коррупционных и иных правонарушений в Республике Татарстан // Реализация антикоррупционной политики в Республике Татарстан: информационный бюллетень: вып. 3 / отв. ред. И.И. Бикеев. - Казань: Изд-во «Познание» Института экономики, управления и права, 2014. - С.160-166.

4. Бикеев И.И., Кабанов П.А. Противодействие коррупции подразделениями кадровых служб органов государственной власти Республики Татарстан: учебная программа. - Казань: Изд-во «Познание» Института экономики, управления и права, 2014.

5. Бикеев И.И., Кабанов П.А., Маклакова А.Н. и др. Организация работы комиссий по соблюдению требований к служебному поведению и урегулированию конфликта интересов в органах местного самоуправления Республики Татарстан: методическое пособие. - Казань, 2012.

6. Бикеев И.И., Кабанов П.А., Чирков Д.К. и др. Коррупция и антикоррупционная политика: терминологический словарь / под общ. ред. Г.И. Райкова, П.А. Кабанова, Д.К. Чиркова. - 5-е изд., перераб. и доп. - М.: МедиаПресс, 2010. - С.9.

7. Будай С.Н. Актуальные вопросы организации в органах прокуратуры работы по профилактике коррупционных правонарушений // Организация работы с кадрами в органах прокуратуры Российской Федерации: сборник материалов. - М., 2012. - С.116-124.

8. Ефременков О.Н. Условия совершенствования работы по профилактике коррупционных правонарушений в системе Следственного комитета Российской Федерации // Вестник Следственного комитета Российской Федерации. - 2013. - № 2 (20). - С.15-20.

9. Методические рекомендации о порядке урегулирования конфликта интересов на государственной гражданской и муниципальной службе Ульяновской области и предотвращения возникновения подобных ситуаций. - Ульяновск: Департамент государственной и муниципальной службы Правительства Ульяновской области, 2014;

10. Методические рекомендации по заполнению справок о доходах, об имуществе и обязательствах имущественного характера для граждан, претендующих на замещение должностей государственной гражданской службы в Ульяновской области, и государственных гражданских служащих Ульяновской области. - Ульяновск: Департамент государственной и муниципальной службы Правительства Ульяновской области, 2014;

11. Методические рекомендации по применению федерального закона от 3 декабря 2013 года №230-Ф3 «0 контроле за соответствием расходов лиц, замещающих государственные должности, и иных лиц их доходам».- Ульяновск: Департамент государственной и муниципальной службы Правительства Ульяновской области, 2014.

12. Мусатов К.В. Функции кадровых подразделений органов прокуратуры по профилактике коррупционных и иных правонарушений // Организация работы с кадрами в органах прокуратуры Российской Федерации: сборник материалов. - М., 2012. - С.76-81.

13. Обеспечение эффективного взаимодействия федеральных органов исполнительной власти с правоохранительными органами в организации противодействия коррупции в федеральных органах исполнительной власти: методические рекомендации, одобренные президиумом Совета при Президенте Российской Федерации по противодействию коррупции 25 сентября 2012 года №34. - М., 2012.

14. Реализация профилактических мероприятий подразделениями кадровых служб федеральных государственных органов по профилактике коррупционных и иных правонарушений: методические рекомендации, одобренные президиумом Совета при Президенте Российской Федерации по противодействию коррупции 25 сентября 2012 года №34. - М., 2012.

15. Функции подразделений кадровых служб федеральных государственных органов по профилактике коррупционных и иных правонарушений: учебная программа. - М., 2010.

16. Шевелевич А.А. Функции подразделений кадровых служб по профилактике коррупционных и иных правонарушений // Противодействие коррупции в федеральных органах исполнительной власти: научно-практическое пособие / отв. ред. А.Ф Ноздрачев. - М., 2012. - С.40-50.

17. Кабанов П.А. Основания и порядок вывода членов Комиссий по соблюдению требований к служебному поведению государственных (муниципальных) служащих и урегулированию конфликта интересов из их состава // Административное и муниципальное право. - 2012. - №3. - С.10-13.

18. Айнур Турисбек Административно-правовое регулирование функций в различных видах государственной службы. // Полицейская деятельность. - 2011. - №3. - С. 8-12.

19. Агеев В.Н. Ограничение прав и свобод муниципальных служащих как способ противодействия коррупции // Тренды и управление. - 2013. - №3. - C. 72-81. DOI: 10.7256/2307-9118.2013.3.7244.

20. Куракин А.В., Костенников М.В. Административно-правовое противодействие коррупции в системе государственной службы и в деятельности сотрудников полиции Российской Федерации и зарубежных государств // NB: Российское полицейское право. - 2013. - №1. - C. 65-83. DOI: 10.7256/2306-4218.2013.1.735. URL: http:// www.e-notabene.ru/pm/article_735.html

21. Кабанов П.А. Антикоррупционное образование как правовая категория регионального антикоррупционного законодательства: опыт критического анализа // Полицейская деятельность. - 2014. - 1. - C. 81 - 92. DOI: 10.7256/2222-1964.2014.1.10653. 


\section{References (transliterated):}

1. Ageev V.N., Bikeev I.I., Kabanov P.A i dr. Vse o korruptsii i protivodeistvii ei: terminologicheskii slovar' / pod obshch. red. I.I. Bikeeva, P.A. Kabanova. - Kazan': Izd-vo «Poznanie» Instituta ekonomki, upravleniya i prava, 2014.

2. Andrichenko L.V., Belyaeva O.A., Vasil'ev I.V. i dr. Protivodeistvie korruptsii v sub"ektakh Rossiiskoi Federatsii: nauchnoprakticheskoe posobie / pod red. T.Ya. Khabrievoi. - M., 2013. - S.135-198.

3. Belov A.N. O deyatel'nosti dolzhnostnykh lits kadrovykh sluzhb organov gosudarstvennoi vlasti i organov mestnogo samoupravleniya po profilaktike korruptsionnykh i inykh pravonarushenii v Respublike Tatarstan // Realizatsiya antikorruptsionnoi politiki v Respublike Tatarstan: informatsionnyi byulleten': vyp. 3 / otv. red. I.I. Bikeev. - Kazan': Izdvo «Poznanie» Instituta ekonomiki, upravleniya i prava, 2014. - S.160-166.

4. Bikeev I.I., Kabanov P.A. Protivodeistvie korruptsii podrazdeleniyami kadrovykh sluzhb organov gosudarstvennoi vlasti Respubliki Tatarstan: uchebnaya programma. - Kazan': Izd-vo «Poznanie» Instituta ekonomiki, upravleniya i prava, 2014.

5. Bikeev I.I., Kabanov P.A., Maklakova A.N. i dr. Organizatsiya raboty komissii po soblyudeniyu trebovanii k sluzhebnomu povedeniyu i uregulirovaniyu konflikta interesov v organakh mestnogo samoupravleniya Respubliki Tatarstan: metodicheskoe posobie. - Kazan', 2012.

6. Bikeev I.I., Kabanov P.A., Chirkov D.K. i dr. Korruptsiya i antikorruptsionnaya politika: terminologicheskii slovar' / pod obshch. red. G.I. Raikova, P.A. Kabanova, D.K. Chirkova. - 5-e izd., pererab. i dop. - M.: MediaPress, 2010. - S.9.

7. Budai S.N. Aktual'nye voprosy organizatsii v organakh prokuratury raboty po profilaktike korruptsionnykh pravonarushenii // Organizatsiya raboty s kadrami v organakh prokuratury Rossiiskoi Federatsii: sbornik materialov. M., 2012. - S.116-124.

8. Efremenkov O.N. Usloviya sovershenstvovaniya raboty po profilaktike korruptsionnykh pravonarushenii v sisteme Sledstvennogo komiteta Rossiiskoi Federatsii // Vestnik Sledstvennogo komiteta Rossiiskoi Federatsii. - 2013. - № 2 (20). - S.15-20.

9. Metodicheskie rekomendatsii o poryadke uregulirovaniya konflikta interesov na gosudarstvennoi grazhdanskoi i munitsipal'noi sluzhbe Ul'yanovskoi oblasti i predotvrashcheniya vozniknoveniya podobnykh situatsii. - Ul'yanovsk: Departament gosudarstvennoi i munitsipal'noi sluzhby Pravitel'stva Ul'yanovskoi oblasti, 2014;

10. Metodicheskie rekomendatsii po zapolneniyu spravok o dokhodakh, ob imushchestve i obyazatel'stvakh imushchestvennogo kharaktera dlya grazhdan, pretenduyushchikh na zameshchenie dolzhnostei gosudarstvennoi grazhdanskoi sluzhby v Ul'yanovskoi oblasti, i gosudarstvennykh grazhdanskikh sluzhashchikh Ul'yanovskoi oblasti. Ul'yanovsk: Departament gosudarstvennoi i munitsipal'noi sluzhby Pravitel'stva Ul'yanovskoi oblasti, 2014;

11. Metodicheskie rekomendatsii po primeneniyu federal'nogo zakona ot 3 dekabrya 2013 goda №230-FZ «O kontrole za sootvetstviem raskhodov lits, zameshchayushchikh gosudarstvennye dolzhnosti, i inykh lits ikh dokhodam». - Ul'yanovsk: Departament gosudarstvennoi i munitsipal'noi sluzhby Pravitel'stva Ul'yanovskoi oblasti, 2014.

12. Musatov K.V. Funktsii kadrovykh podrazdelenii organov prokuratury po profilaktike korruptsionnykh i inykh pravonarushenii // Organizatsiya raboty s kadrami v organakh prokuratury Rossiiskoi Federatsii: sbornik materialov. M., 2012. - S.76-81.

13. Obespechenie effektivnogo vzaimodeistviya federal'nykh organov ispolnitel'noi vlasti s pravookhranitel'nymi organami $\mathrm{v}$ organizatsii protivodeistviya korruptsii v federal'nykh organakh ispolnitel'noi vlasti: metodicheskie rekomendatsii, odobrennye prezidiumom Soveta pri Prezidente Rossiiskoi Federatsii po protivodeistviyu korruptsii 25 sentyabrya 2012 goda №34. - M., 2012.

14. Realizatsiya profilakticheskikh meropriyatii podrazdeleniyami kadrovykh sluzhb federal'nykh gosudarstvennykh organov po profilaktike korruptsionnykh i inykh pravonarushenii: metodicheskie rekomendatsii, odobrennye prezidiumom Soveta pri Prezidente Rossiiskoi Federatsii po protivodeistviyu korruptsii 25 sentyabrya 2012 goda №34. - M., 2012.

15. Funktsii podrazdelenii kadrovykh sluzhb federal'nykh gosudarstvennykh organov po profilaktike korruptsionnykh i inykh pravonarushenii: uchebnaya programma. - M., 2010.

16. Shevelevich A.A. Funktsii podrazdelenii kadrovykh sluzhb po profilaktike korruptsionnykh i inykh pravonarushenii // Protivodeistvie korruptsii v federal'nykh organakh ispolnitel'noi vlasti: nauchno-prakticheskoe posobie / otv. red. A.F Nozdrachev. - M., 2012. - S.40-50.

17. Kabanov P.A. Osnovaniya i poryadok vyvoda chlenov Komissii po soblyudeniyu trebovanii k sluzhebnomu povedeniyu gosudarstvennykh (munitsipal'nykh) sluzhashchikh i uregulirovaniyu konflikta interesov iz ikh sostava // Administrativnoe i munitsipal'noe pravo. - 2012. - №3. - S.10-13.

18. Ainur Turisbek Administrativno-pravovoe regulirovanie funktsii v razlichnykh vidakh gosudarstvennoi sluzhby. // Politseiskaya deyatel'nost'. - 2011. - №3. - S. 8-12.

19. Ageev V.N. Ogranichenie prav i svobod munitsipal'nykh sluzhashchikh kak sposob protivodeistviya korruptsii // Trendy i upravlenie. - 2013. - №3. - S. 72-81. DOI: 10.7256/2307-9118.2013.3.7244.

20. Kurakin A.V., Kostennikov M.V. Administrativno-pravovoe protivodeistvie korruptsii v sisteme gosudarstvennoi sluzhby i v deyatel'nosti sotrudnikov politsii Rossiiskoi Federatsii i zarubezhnykh gosudarstv // NB: Rossiiskoe politseiskoe pravo. 2013. - №1. - S. 65-83. DOI: 10.7256/2306-4218.2013.1.735. URL: http://www.e-notabene.ru/pm/article_735.html

21. Kabanov P.A. Antikorruptsionnoe obrazovanie kak pravovaya kategoriya regional'nogo antikorruptsionnogo zakonodatel'stva: opyt kriticheskogo analiza // Politseiskaya deyatel'nost'. - 2014. - 1. - S. 81 - 92. D0I: 10.7256/22221964.2014.1.10653. 